\title{
Brazilian natural fiber (jute) as raw material for activated carbon production
}

\author{
CARLA F.S. ROMBALDO ${ }^{1}$, ANTONIO C.L. LISBOA ${ }^{1}$, \\ MANOEL O.A. MENDEZ ${ }^{2}$ and APARECIDO R. COUTINHO ${ }^{2}$ \\ ${ }^{1}$ Universidade Estadual de Campinas, Faculdade de Engenharia Química, \\ Av. Albert Einstein, 500, 13083-852 Campinas, SP, Brasil \\ ${ }^{2}$ Universidade Metodista de Piracicaba, Laboratório de Materiais Carbonosos, \\ Rodovia SP 306, Km 1, 13451-900 Santa Bárbara d'Oeste, SP, Brasil
}

Manuscript received on March 25, 2014, accepted for publication on August 4, 2014

\begin{abstract}
Jute fiber is the second most common natural cellulose fiber worldwide, especially in recent years, due to its excellent physical, chemical and structural properties. The objective of this paper was to investigate: the thermal degradation of in natura jute fiber, and the production and characterization of the generated activated carbon. The production consisted of carbonization of the jute fiber and activation with steam. During the activation step the amorphous carbon produced in the initial carbonization step reacted with oxidizing gas, forming new pores and opening closed pores, which enhanced the adsorptive capacity of the activated carbon. $\mathrm{N}_{2}$ gas adsorption at $77 \mathrm{~K}$ was used in order to evaluate the effect of the carbonization and activation steps. The results of the adsorption indicate the possibility of producing a porous material with a combination of microporous and mesoporous structure, depending on the parameters used in the processes, with resulting specific surface area around $470 \mathrm{~m}^{2} \cdot \mathrm{g}^{-1}$. The thermal analysis indicates that above $600^{\circ} \mathrm{C}$ there is no significant mass loss.
\end{abstract}

Key words: activation, adsorption, carbonization, jute fiber, thermogravimetry.

\section{INTRODUCTION}

Jute fiber is by far the most common natural fiber in the world. Its use has increased significantly due to its unique combination of physical, chemical and structural properties, and also due to the growing concern with the environment (Alves et al. 2010, Zhou et al. 2013). The characteristics of a typical jute fiber are shown in Table I.

There is a growing interest regarding the use of lignocellulosic materials such as jute, sisal, coconut, banana and curauá fibers as precursors for

Correspondence to: Carla Fabiana S. Rombaldo

E-mail: cfrombaldo@unimep.br the production of activated carbon (Asadullah et al. 2013, Roy et al. 2012, Williams and Reed 2006, Phan et al. 2006, Senthilkumaar et al. 2005) as well as to strengthen polymeric matrixes of composites (Ramesh et al 2013, Ku et al. 2011).

Ioannidou and Zabaniotou 2007 mention that activated carbon from natural fibers exhibit specific surface areas ranging from $80 \mathrm{~m}^{2} \cdot \mathrm{g}^{-1}$ to $900 \mathrm{~m}^{2} \cdot \mathrm{g}^{-1}$, with porous structure containing mostly micropores when produced at heating rates of $2^{\circ} \mathrm{C}$. $\mathrm{min}^{-1}$, at temperatures between $200^{\circ} \mathrm{C}$ and $300^{\circ} \mathrm{C}$ during carbonization and at activation heating rates of $4^{\circ} \mathrm{C} \cdot \mathrm{min}^{-1}$, with final temperature of $800^{\circ} \mathrm{C}$. 
TABLE I

Characterization of in natura jute fiber (Bledzki and Gassan 1999, Phan et al. 2006, Ramesh et al. 2013).

\begin{tabular}{cccc}
\hline Parameter & Bledzki and Gassan 1999 & $\begin{array}{c}\text { Phan } \\
\text { et al. 2006 }\end{array}$ & $\begin{array}{c}\text { Ramesh } \\
\text { et al. 2013 }\end{array}$ \\
\hline Cellulose & $64.4 \%^{\mathrm{a}}$ & $58.0 \%-63.0 \%$ & $50.0 \%-57.0 \%$ \\
Hemicellulose & $12.0 \%$ & $20.0 \%-22.0 \%$ & - \\
Lignin & $11.8 \%$ & $12.0 \%-15.0 \%$ & $8.0 \%-10.0 \%$ \\
Water soluble & $1.1 \%$ & - & - \\
Water & $10.0 \%$ & - & - \\
Wax & $0.5 \%$ & - & - \\
Density & $1.3{\mathrm{~g} . \mathrm{cm}^{-3}}^{-3}$ & - & $1.4 \mathrm{g.cm}^{-3}$ \\
Elongation & $1.5 \%-1.8 \%$ & - & $1.8 \%$ \\
Tensile strength & $393 \mathrm{MPa}-773 \mathrm{MPa}$ & - & $400 \mathrm{MPa}-800 \mathrm{MPa}$ \\
Young's modulus & $26.5 \mathrm{GPa}$ & - & $30.0 \mathrm{GPa}$ \\
\hline
\end{tabular}

${ }^{\mathrm{a}}$ mass based values

Some studies have indicated that activated carbon from natural fibers reach adsorption rates 2 to 50 times faster the ones from coal, due to the small diameter of the fibers, around $10 \mu \mathrm{m}$, presenting a larger external surface area in contact with the fluid (Baudu et al. 1991). Furthermore some studies have shown its potential to withdraw water pollutants such as phenol, pesticides and dyes (Asadullah et al. 2013, 2010, Banerjee and Dastidar 2005, Hameed et al. 2007, Ahmaruzzaman and Gayatri 2010, Kumar et al. 2008).

Aiming at the use of available natural resources and the search for economical alternatives for activated carbon production, the objective of this work was to characterize the jute fiber (in natura) and to produce and characterize the resulting activated carbon.

\section{MATERIALS AND METHODS}

\section{CHARACTERIZATION OF IN NATURA JUTE FIBER AND}

ACTIVATED CARBON PRODUCED

Thermal analyses were carried out with an analyzer from NETZSCH, model TG 209, with controller also from NETZSCH, model TASC 414/3. They used $5 \mathrm{mg}$ samples, with final temperature of $950^{\circ} \mathrm{C}$ and heating rates of $1^{\circ} \mathrm{C} \cdot \mathrm{min}^{-1}, 3^{\circ} \mathrm{C} \cdot \mathrm{min}^{-1}, 5^{\circ} \mathrm{C} \cdot \mathrm{min}^{-1}$ and $10^{\circ} \mathrm{C} \cdot \mathrm{min}^{-1}$.
Immediate analyses were carried out in order to determine the moisture content as well as the ash, volatile and fixed carbon contents. The analyses followed norm D1762-84 reviewed in 1985 (ASTM), which addresses such analyses for char and wood substances.

The activated carbon was characterized by gas adsorption $\left(\mathrm{N}_{2}\right.$ at $\left.77 \mathrm{~K}\right)$. All samples were degassed under vacuum at $150^{\circ} \mathrm{C}$, and a gas adsorption analyzer (Quantachrome Corp. model Autosorb$1 \mathrm{MP})$ was used to measure the pore distribution, pore volume and specific surface area. Data from the adsorption isotherms for nitrogen at $77 \mathrm{~K}$ were used to determine the specific surface area according to the method proposed by Brunauer, Emmet and Teller (Rouquerol 1994, IUPAC 1985). The micropore (pore diameter narrower than $2.0 \mathrm{~nm}$ ) area was obtained by applying the t-plot method. The total pore volume was determined by converting the volume adsorbed at the saturation point $\mathrm{P} / \mathrm{P}_{\mathrm{o}} \approx 0.99$ into liquid volume, whilst the micropore volume was calculated at the point of interception of the linear region of the t-plot after saturation of the micropores.

CARbonization And Activation of JUTE Fiber

The raw material was submitted to carbonization followed immediately by activation in the same 
run. Samples $190 \mathrm{~mm}$ long were placed within a quartz reactor capable of accommodating $50 \mathrm{~g}$.

The experimental set-up is shown in Figure 1. Heat was supplied by an electrically heated $630 \mathrm{~mm}$ vertical furnace (1) to a $700 \mathrm{~mm}$ long $60 \mathrm{~mm}$ diameter quartz reactor (2). Temperature and heating rates were controlled (3). A flask (9) was heated by resistances (8) connected to a power source (11). Temperatures were measured by thermocouples inside (4) and outside (5) the reactor as well as inside the flask (10). The whole set-up was placed under an exhausting system (6) to vent off gases.

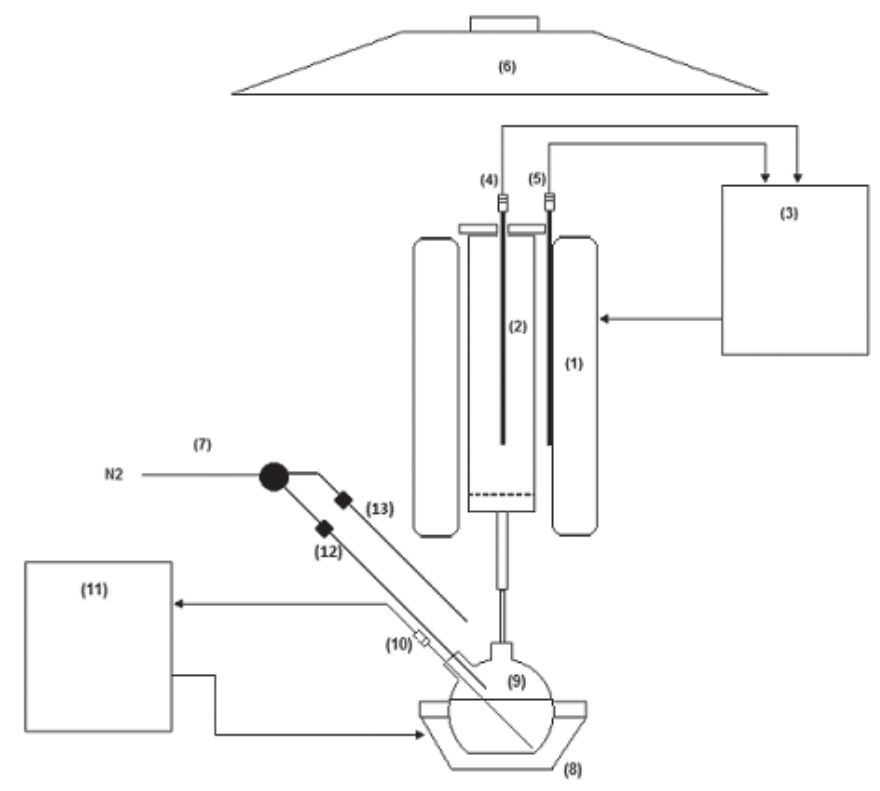

Figure 1 - Apparatus for carbonization and activation of jute fibers.

The $\mathrm{N}_{2}$ flow rates to carry steam were previously tested and defined for all experiments: $200 \mathrm{~mL} \cdot \mathrm{min}^{-1}$ of $\mathrm{N}_{2}$ carried $0.17 \mathrm{~mL} \cdot \mathrm{min}^{-1}$ of water (activation steam), $300 \mathrm{~mL} \cdot \mathrm{min}^{-1}$ of $\mathrm{N}_{2}$ carried $0.33 \mathrm{~mL} \cdot \mathrm{min}^{-1}$ of water and $400 \mathrm{~mL} \cdot \mathrm{min}^{-1}$ of $\mathrm{N}_{2}$ carried $0.50 \mathrm{~mL} \cdot \mathrm{min}^{-1}$ of water.

Figure 2 shows the temperature profile selected for the production of steam activated jute fiber.

Some preliminary runs were carried out to determine the experimental parameter values. Temperatures below $600^{\circ} \mathrm{C}(\mathrm{T} 2)$ produced activated carbons with too low specific surface area. Above $800^{\circ} \mathrm{C}$ the material was totally or partially degraded. Within these limits the following conditions were specified.

Conditions for the carbonization step: heating rate up to temperature $\mathrm{T} 1: 3^{\circ} \mathrm{C} \cdot \mathrm{min}^{-1}$; carbonization temperature (T1): $350^{\circ} \mathrm{C}$; carbonization residence time: $(\mathrm{t} 1-\mathrm{t} 2)$ : $30 \mathrm{~min}$; inert gas $\left(\mathrm{N}_{2}\right)$ flow rate: $200 \mathrm{~mL} \cdot \mathrm{min}^{-1}$.

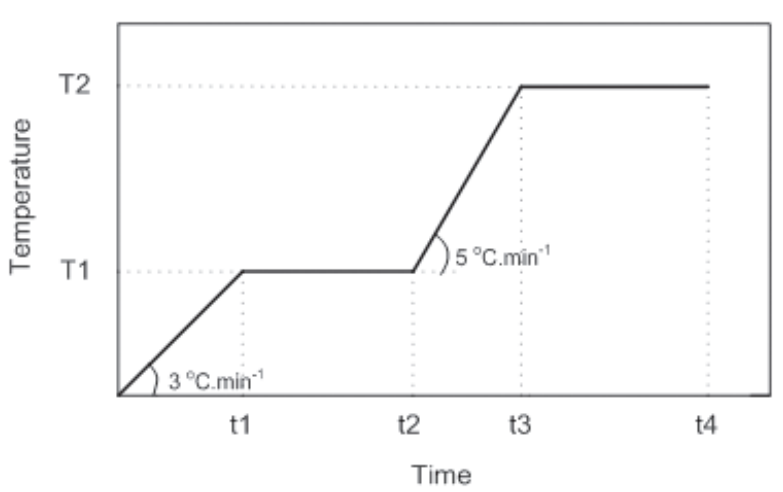

Figure 2 - Temperature profile for the production of activated carbon from jute fiber.

Conditions defined for the activation step:

heating rate: $5^{\circ} \mathrm{C} \cdot \mathrm{min}^{-1}$;

activation temperature (T2): $600^{\circ} \mathrm{C}-800^{\circ} \mathrm{C}$;

activation residence time ( $\mathrm{t} 2-\mathrm{t} 3): 30 \mathrm{~min}-90 \mathrm{~min}$;

inert gas $\left(\mathrm{N}_{2}\right)$ flow rate: $200 \mathrm{~mL} \cdot \mathrm{min}^{-1}-400 \mathrm{~mL} \cdot \mathrm{min}^{-1}$. 
The heating rate used in the carbonization process and the activation process were based on information from previous values (Asadullah et al. 2010, Wu et al. 2013, Ioannidou and Zabaniotou 2007) and adapted to the result of immediate analyses.

Table II shows the variables investigated and their range of values used during the production of activated jute fibers.

\section{TABLE II}

Activated carbon production process parameters.

\begin{tabular}{llll}
\hline Variables & $\mathbf{- 1}$ & $\mathbf{0}$ & $+\mathbf{1}$ \\
\hline$\left(\mathrm{X}_{1}\right)$ Temperature $\left({ }^{\circ} \mathrm{C}\right)$ & 600 & 700 & 800 \\
$\left(\mathrm{X}_{2}\right)$ Activation time $(\mathrm{min})$ & 30 & 60 & 90 \\
$\left(\mathrm{X}_{3}\right) \mathrm{N}_{2}$ flow rate for carrying steam $\left(\mathrm{mL} \cdot \mathrm{min}^{-1}\right)$ & 200 & 300 & 400 \\
\hline
\end{tabular}

\section{RESULTS AND DISCUSSION}

THERMOGRAVIMETRIC ANALYSIS OF IN NATURA JUTE FIBER

The thermogravimetry (TG) was carried out with inert gas $\left(20 \mathrm{~mL} \cdot \mathrm{min}^{-1}\right.$ of $\left.\mathrm{N}_{2}\right)$, carbonic gas $\left(20 \mathrm{~mL} \cdot \mathrm{min}^{-1}\right)$ and synthetic air (mixture of $\mathrm{N}_{2} 20 \mathrm{~mL} \cdot \mathrm{min}^{-1}$ and $\left.\mathrm{O}_{2} 8 \mathrm{~mL} \cdot \mathrm{min}^{-1}\right)$. Four heating rates were employed: $1^{\circ} \mathrm{C} \cdot \mathrm{min}^{-1}, 3^{\circ} \mathrm{C} \cdot \mathrm{min}^{-1}, 5^{\circ} \mathrm{C} \cdot \mathrm{min}^{-1}$ and $10^{\circ} \mathrm{C} \cdot \mathrm{min}^{-1}$. All analyses employed samples of $5 \mathrm{mg}$ and final temperature of $950^{\circ} \mathrm{C}$.

The TG curves of in natura jute fibers with inert atmosphere, synthetic air and $\mathrm{CO}_{2}$ are presented in Figures $3 \mathrm{~A}, 3 \mathrm{C}$ and $3 \mathrm{E}$, respectively. Their respective first derivative thermogravimetry (DTG) curves are presented in Figures 3B, 3D and 3F.

Figures $3 \mathrm{~A}, 3 \mathrm{C}$ and $3 \mathrm{D}$ show that the heating rate did not affect the mass losses, indicating they depend only on temperature. Jute fiber degradation starts at about $260^{\circ} \mathrm{C}$ and proceeds fast with temperature rise. This behavior was also noticed by Cao et al. 2013, Monteiro et al. 2012 and by Banerjee and Dastidar 2005.

Comparing the DTG curve using inert gas (Figure 3B) with two other gases (Figures 3D and $3 \mathrm{~F})$, one observes that the first peak (9.5\% mass loss) around $80^{\circ} \mathrm{C}$ is common to both situations, which is due to the loss of adsorbed water in fiber (intra and intermolecular dehydration reactions); the second peak is also common, accounting for the major organic material loss (cellulose and hemicellulose), between $330^{\circ} \mathrm{C}$ and $380^{\circ} \mathrm{C}$. However the third peak which appears when using $\mathrm{O}_{2}$, indicating the loss of material due to an oxidizing reaction involving the lignin. For all situations, i.e., for all types of gases, all material loss occurs below $600^{\circ} \mathrm{C}$.

\section{CHARACTERIZATION OF ACTIVATED CARBON FrOM}

JUTE FIBER

Jute fiber (in natura) presented moisture content of $9 \%$, volatile content of $84 \%$, ash content of $9 \%$ and fixed carbon content of $7 \%$. In order to grant total volatile elimination, the heating rate must be low during the carbonization period, which also boosts pore formation.

Table III shows the variables investigated and the answer for yield ( $\eta$ ) and specific surface area (SSA) for the jute fiber carbonization and activation with steam.

TABLE III

Experimental planning matrix with answers for yield $(\eta)$ and specific surface area (SSA).

\begin{tabular}{cccccc}
\hline Sample & $\mathbf{X}_{\mathbf{1}}$ & $\mathbf{X}_{\mathbf{2}}$ & $\mathbf{X}_{\mathbf{3}}$ & $\begin{array}{c}\mathbf{\eta} \\
\mathbf{( \% )}\end{array}$ & $\begin{array}{c}\mathbf{S S A} \\
\left(\mathbf{m}^{\mathbf{2}} \cdot \mathbf{g}^{-\mathbf{1}}\right)\end{array}$ \\
\hline JFA1 & -1 & -1 & -1 & 20.67 & 361.50 \\
JFA2 & 1 & -1 & -1 & 18.61 & 475.70 \\
JFA3 & -1 & 1 & -1 & 19.95 & 396.00 \\
JFA4 & 1 & 1 & -1 & 17.33 & 477.00 \\
JFA5 & -1 & -1 & 1 & 20.09 & 412.20 \\
JFA6 & 1 & -1 & 1 & 16.26 & 547.90 \\
JFA7 & -1 & 1 & 1 & 17.88 & 453.50 \\
JFA8 & 1 & 1 & 1 & 11.46 & 748.90 \\
JFA9 & 0 & 0 & 0 & 17.82 & 446.10 \\
JFA10 & 0 & 0 & 0 & 19.56 & 404.10 \\
JFA11 & 0 & 0 & 0 & 18.13 & 444.30 \\
\hline
\end{tabular}

The data in Table III indicate a mass based average yield of $18 \%$ and average specific surface area of $470 \mathrm{~m}^{2} \cdot \mathrm{g}^{-1}$. The highest the variable levels, the lowest the yield, and the highest the SSA. 

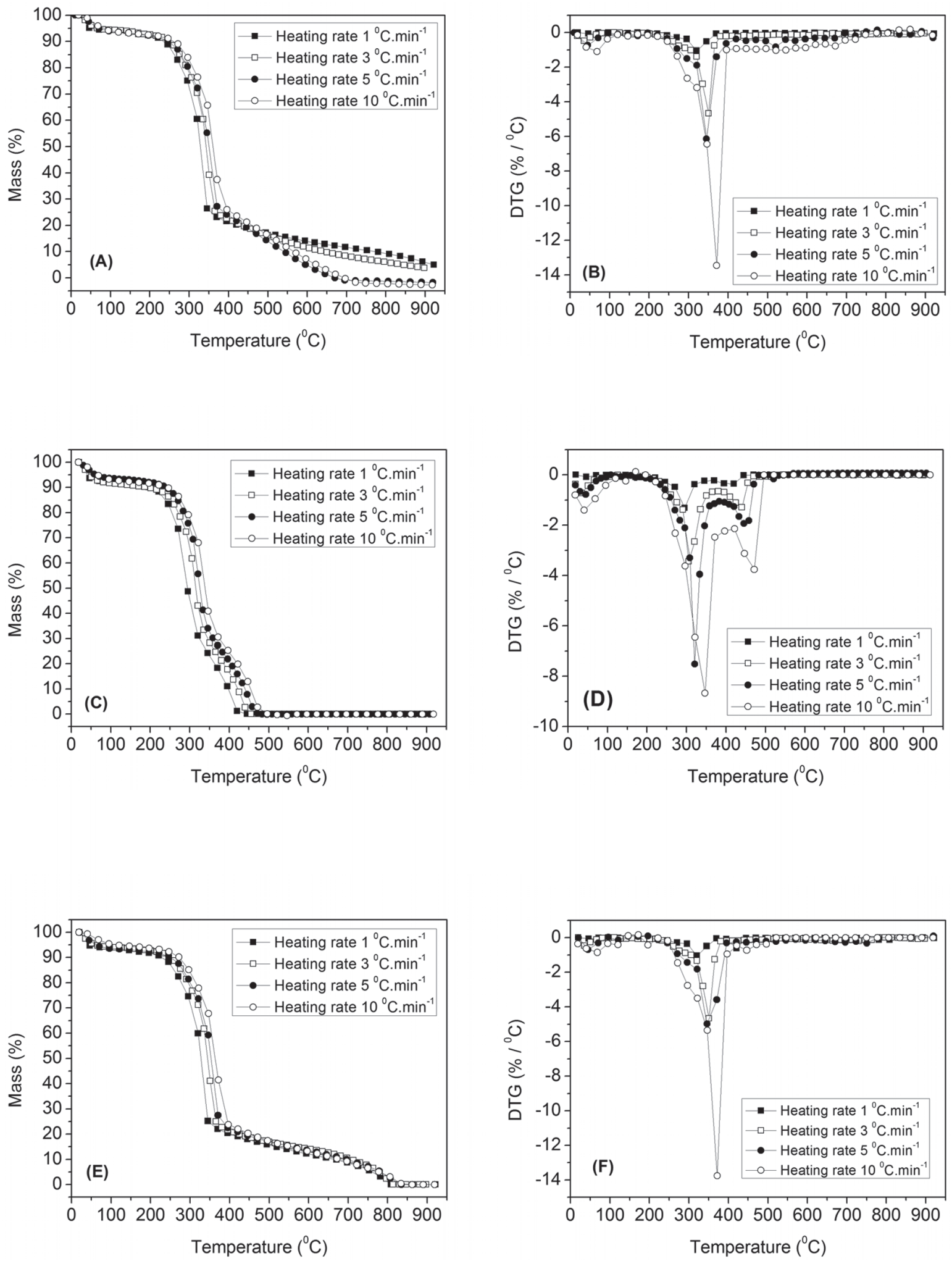

Fig. 3 - Jute fiber (in natura) thermogravimetry (TG) curves and derivate thermogravimetry (DTG) curves: (A) TG with inert gas; (B) DTG with inert gas; (C) TG with synthetic air; (D) DTG with synthetic air; (E) TG with $\mathrm{CO}_{2}$; (F) DTG with $\mathrm{CO}_{2}$. 
At the lowest temperatures and activations times, the highest yields were obtained, although with the lowest SSA values.

The low yield can be explained by the elimination of the large amount of volatile matter present in the raw material (carbonization) as well as by the reaction between fixed carbon and steam (activation). The yields obtained varied inversely with temperature. These results are in agreement with the ones from Asadullah et al. 2010.

The specific surface values vary proportionally with temperature, with maximum value $\left(730 \mathrm{~m}^{2} \cdot \mathrm{g}^{-1}\right)$ at $700^{\circ} \mathrm{C}$, when starting the destruction pore wall.

Figure 4 shows the $\mathrm{N}_{2}(77 \mathrm{~K})$ adsorption/desorption isotherms of activated carbon from jute fiber.

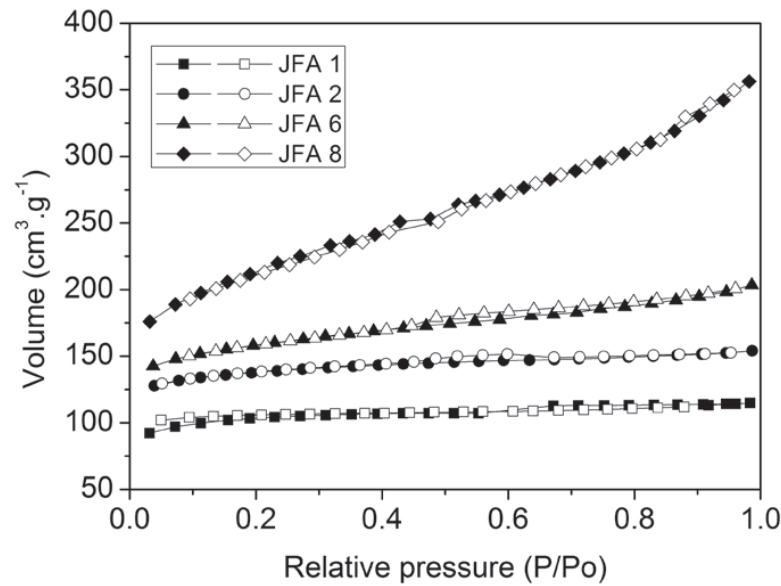

Fig. 4 - Adsorption (open symbols) and desorption (closed symbols) isotherms of $\mathrm{N}_{2}$ at $77 \mathrm{~K}$.

The isotherms of Figure 4 show similar trend except JFA8 that presents an increase in the adsorption capacity at higher relative pressures. There was no hysteresis, which indicates no capillary condensation, typical of macro and meso pores. Sample JFA1 exhibited the lowest adsorption capacity, as also obtained by Asadullah et al. 2014.

Table IV shows that activated carbon from jute fiber is widely microporous. Around $95 \%$ of SSA belongs to micropores and $90 \%$ of the pore volume belongs to micropores. Only sample JF8 showed an average pore diameters larger than
$2 \mathrm{~nm}(2.95 \mathrm{~nm})$. All other samples had average pore diameter narrower than $2 \mathrm{~nm}$ (according to IUPAC micropores). It is possible to conclude that the activated carbon obtained from the jute fiber is essentially microporous.

The increase of SSA is mostly related to wall destruction, turning micropores into mesopores, and not to the creation of new pores. This phenomenon has been reported in previous investigations (Phan et al. 2006, Asadullah et al. 2014).

Figure 5A shows pore size distributions of two samples (JFA1 and JFA2) and Figure 5B shows pore size distributions of JFA6 and JFA8, all obtained according to the Non-Local Density Functional Theory (NLDFT). Sample JFA1 exhibits just one peak, which is inside the micropore region (less than $2 \mathrm{~nm}$ ), confirming the data from the $\mathrm{N}_{2}$ isotherms, coherent with the $98 \%$ of micropores in the sample. Sample JFA2 also contains a large presence of micropores (diameter narrower than $5 \mathrm{~nm}$ ). Samples JFA6 and JFA8 have similar behavior, with large incidence of micropores and two other smaller peaks in the mesopore region, in agreement with the data from Table IV, with area composed of $93 \%$ of micropores and only $7 \%$ pores with diameter wider than $5 \mathrm{~nm}$. The percentage of volume in the micropore region of these samples is $85 \%$.

\section{CONCLUSIONS}

The thermogravimetric analysis heating rate did not affect the mass losses, indicating they depend only on temperature. The major portion of the volatile matter was removed within the range $260^{\circ} \mathrm{C}-430^{\circ} \mathrm{C}$. Above $600^{\circ} \mathrm{C}$ there is no significant mass loss. For the inert and carbonic gas atmospheres the thermogramimetric analysis indicates the presence of two peaks of mass loss while for the synthetic air atmosphere it indicates the presence of three peaks of mass loss.

A mass based average yield of $18 \%$ and an average specific surface area of $470 \mathrm{~m}^{2} \cdot \mathrm{g}^{-1}$ was observed. The activated carbon from jute fiber structure characterization indicates a microporous 
Table IV

Activated carbon structure related data.

\begin{tabular}{lllll}
\hline Analysis & JFA1 & JFA2 & JFA6 & JFA8 \\
\hline Surface area data & & & & \\
Multi BET $\left(\mathrm{m}^{2} \cdot \mathrm{g}^{-1}\right)$ & 361.50 & 475.70 & 547.90 & 748.90 \\
t-method external surface area $\left(\mathrm{m}^{2} \cdot \mathrm{g}^{-1}\right)$ & 1.74 & 3.90 & 15.60 & 53.00 \\
t-method micropore area $\left(\mathrm{m}^{2} \cdot \mathrm{g}^{-1}\right)$ & 359.80 & 471.80 & 532.30 & 695.80 \\
NLDFT method cumulative surface area $\left(\mathrm{m}^{2} \cdot \mathrm{g}^{-1}\right)$ & 357.80 & 422.40 & 467.90 & 596.50 \\
Micropore surface area $(\%)$ & 99.50 & 99.20 & 93.7 & 92.90 \\
\hline Pore volume data & & & & \\
Total pore volume for pores with diameter less & 0.18 & 0.24 & 0.31 & 0.55 \\
than 1083.4 A at P/Po $=0.98173\left(\mathrm{~cm}^{3} \cdot \mathrm{g}^{-1}\right)$ & 0.17 & 0.23 & 0.28 & 0.44 \\
t-method micropore volume $\left(\mathrm{cm}^{3} \cdot \mathrm{g}^{-1}\right)$ & 0.16 & 0.21 & 0.28 & 0.50 \\
NLDFT method cumulative pore volume $\left(\mathrm{cm}^{3} \cdot \mathrm{g}^{-1}\right)$ & 97.80 & 95.90 & 88.30 & 79.00 \\
Micropore volume $(\%)$ & & & & \\
\hline Pore size data & 1.97 & 2.00 & 2.30 & 2.95 \\
Average pore diameter $(\mathrm{nm})$ & 1.54 & 1.54 & 1.54 & 1.47 \\
NLDFT method pore diameter $(\mathrm{Mode})(\mathrm{nm})$ & & & & \\
\hline
\end{tabular}
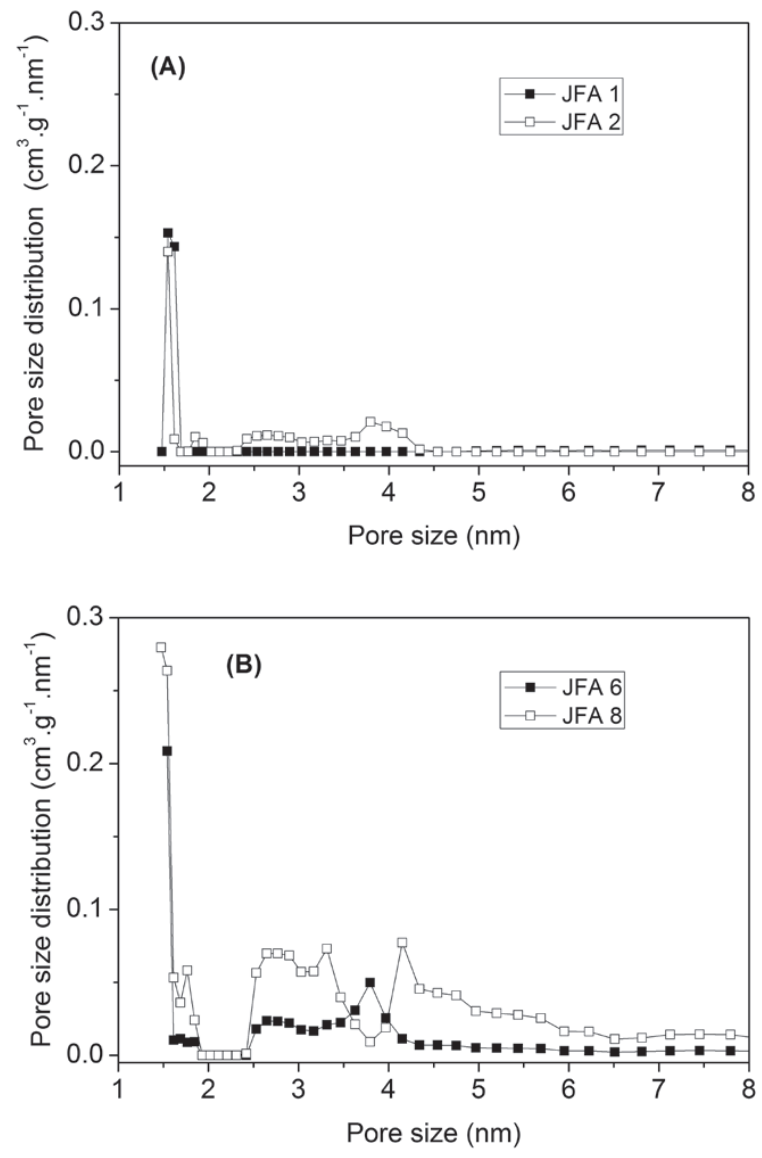

Fig. 5 - Pore size distribution: (A) sample JFA1 and JFA 2; (B) sample JFA6 and JFA8. material with minor presence of mesopores, although this may be changed by activation conditions. Mild temperatures and mild steam flow rates produce low specific surface areas. The porous structure is made up of micropores, totalling $92 \%$ of total volume. It was also observed that extreme activation times and gas flow rates result in higher surface areas, but still with high concentration of micropores. Therefore the jute fibers proved to be a good and versatile precursor of activated carbon.

\section{RESUMO}

A fibra de juta é a segunda fibra natural de celulose mais comum no mundo, especialmente nos últimos anos, em virtude de suas excelentes propriedades físicas, químicas e estruturais. O objetivo deste trabalho foi investigar: a degradação térmica da fibra de juta in natura, e a produção e caracterização do carvão ativado obtido. A produção consistiu na carbonização e ativação com vapor d'água da fibra de juta. Durante a etapa de ativação, o carbono amorfo produzido na fase inicial de carbonização reagiu com gás oxidante, formando novos poros e abrindo os poros fechados, o que aumenta a capacidade de adsorção do carvão ativado. Adsorção de $\mathrm{N}_{2}$ a $77 \mathrm{~K}$ foi usada para 
avaliar o efeito das etapas de carbonização e ativação. Os resultados da adsorção indicam a possibilidade de produzir um material poroso com uma combinação de estrutura microporosa e mesoporosa, dependendo dos parâmetros utilizados nos processos, com área superficial específica em torno $470 \mathrm{~m}^{2} \cdot \mathrm{g}^{-1}$. A análise térmica indica que acima de $600^{\circ} \mathrm{C}$ não há perda significativa de massa.

Palavras-chave: ativação, adsorção, carbonização, fibra de juta, termogravimetria.

\section{REFERENCES}

Alves C, Ferrão PMC, Silva AJ, Reis LG, Freitas M, RODRIGUES LB AND ALVES DE. 2010. Ecodesign of automotive components making use of natural jute fiber composites. J Cleaner Prod 18: 313-327.

AHMARUZZAMAN M AND GAYATRI SL. 2010. Batch adsorption of 4-nitrophenol by acid activated jute stick char: equilibrium, kinetic and thermodynamic studies. Chem Eng J 158: 173-180.

Asadullah M, AsaduZzaman M, Kabir MS, Mostofa MG AND MiYAZAWA T. 2010. Chemical and structural evaluation of activated carbon prepared from jute sticks for Brilliant Green dye removal from aqueous solution. J Hazard Mater 174: 437-443.

Asadullah M, Jahan I, AhMEd MB, AdaWiyah P, MaleK NH AND RAHMAN MS. 2014. Preparation of microporous activated carbon and its modification for arsenic removal from water. J Ind Eng Chem 20: 887-896.

AsADUllah M, KaBIR MS, AHMED MB, RAZAK NA, RASID NSA AND AEZZIRA A. 2013. Role of microporosity and surface functionality of activated carbon in methylene blue dye from water. Koren J Chem Eng 30: 2228-2234.

ASTM. 2001. Designation: D 1762 - 84: Standard Test Method for Chemical Analysis of Wood Charcoal, United States.

BANERJEE S AND DASTIDAR MG. 2005. Use of jute processing wastes for treatment of wastewater contaminated with dye and other organics. Bioresour Technol 96: 1919-1928.

Baudu M, Le Cloirece P And Martin G. 1991. Pollutant adsorption onto activated carbon menbranes. Water Sci Technol 23: 1659-1666.

BLEDZKI AK AND GASSAN J. 1999. Composites reinforced with cellulose based fibres. Prog Polym Sci 24: 221-274.

CAO X, Ding B, YU J AND AL-DEYAB SS. 2013. In situ growth of silver nanoparticles on TEMPO-oxidized jute fibers by microwave heating. Carbohyd Polym 92: 571-576.
HAMEED BH, AHMAD AL AND LATIFF KNA. 2007. Adsorption of basic dye (methylene blue) onto activated carbon prepared from rattan sawdust. Dyes Pigm 75: 143-149.

IOANNIDOU O AND ZABANIOTOU A. 2007. Agricultural residues as precursors for activated carbon production - A review. Renew Sust Energ Rev 11: 1966-2005.

IUPAC. 1985. Reporting Physisorption data for gas solid systems with special reference to the determination of surface-area and porosity (recommendations 1984). Pure Appl Chem 57: 603-619.

Ku H, Wang H, Pattarachaiyakoop N and Trada M. 2011. A review on the tensile properties of natural fiber reinforced polymer composites. Composites Part B 42: 856-873.

KUMAR PA, CHAKRABORTY S AND RAY M. 2008. Removal and recovery of chromium from wastewater using short chain polyaniline synthesized on jute fiber. Chem Eng J 141: 130-140.

Monteiro SN, Calado V, Rodriguez RJ and Margem FM. 2012. Thermogravimetric behavior of natural fibers reinforced polymer composites- An overview. Mater Sci Eng A 557: 17-28.

Phan NH, Rio S, Faur C, Le CoQ L, Le Cloirec P AND NGUYEN TH. 2006. Production of fibrous activated carbons from natural cellulose (jute, coconut) fibers for water treatment applications. Carbon 44: 2569-2577.

RAMESH M, PALANIKUMAR K AND HEMACHANDRA REDDY K 2013. Mechanical property evaluation of sisal-jute-glass fiber reinforced. Composites Part B 48: 1-9.

ROUQUEROL J. 1994. Recommendations for the characterization of porous solids. Pure Appl Chem 66: 1739-1758.

RoY A, CHAKRABORTY S, KUNDU SP, BASAK RK, MAJUMDER SB AND ADHIKARI B. 2012. Improvement in mechanical properties of jute fibres through mild alkali treatment as demonstrated by utilisation of the Weibull distribution model. Bioresour Technol 107: 222-228.

SENTHILKUMAar S, VARADARAJAN PR, PORKODI K AND SUBBHURAAM CV. 2005. Adsorption of methylene blue onto jute fiber carbon: kinetics and equilibrium studies. J Colloid Interface Sci 284: 78-82.

WILLIAMS PT AND REED AR. 2006. Development of activated carbon pore structure via physical and chemical activation of biomass fibre waste. Biomass Bioenerg 30: 144-152.

WU H, FAN S, YUAN X, CHEN L AND DENG J. 2013. Fabrication of carbon fibers from jute fibers by peroxidation and carbonization. New Carbon Materials 28: 448-453.

Zhou X, Ghaffar SH, Dong W, Oladiran O AND Fan M. 2013. Fracture and impact properties of short discrete jute fibre-reinforced cementitious composites. Mater Des 49: 35-47. 